'Cooking' at lower temperatures $-26^{\circ} \mathrm{C}$ was optimal - produced an accumulation of mature, terminally glycosylated molecules at the plasma membrane. By structural and functional criteria, these molecules behave like no other class I MHC molecules previously studied and have properties appropriate for unstable, peptide-free dimers of heavy chain and $\beta 2 \mathrm{~m}$ (see table). Ljunggren et al. call them "empty class I molecules that come out in the cold"t.

But empty class I molecules also seem to come out in 'the hot' (or at any rate at 37 ${ }^{\circ} \mathrm{C}$ ); although like Leamas, the spy who came in from the cold in Le Carré's novel', they do not survive long on arrival. At 37 ${ }^{\circ} \mathrm{C}$, most $\mathrm{H}-2$ heavy chains in RMA-S cells never reach the plasma membrane, but the results of Ljunggren et al. indicate that a small proportion continuously arrive as empty molecules, which then rapidly fall apart. Empty molecules can, however, be stabilized by the binding of an exogenously added peptide (see figure), and also by the binding of specific anti-H-2 monoclonal antibodies (G. Hämmerling and V. Ortiz-Navarrete, personal communication). The unexpected observation that empty class I molecules reach the cell surface and can be rescued there by peptide binding suggests an alternative and less radical interpretation to that favoured by Townsend et al. from the original peptide-feeding experiments ${ }^{2}$

Their interpretation was that peptides use an unusual pathway of intracellular transport to enter cells and facilitate classI assembly in the endoplasmic reticulum, the alternative merely requires that they have access to the cell surface. Although the first interpretation is not excluded, the simpler alternative can reasonably explain the existing data. Prolonged incubation with peptide - as in the original feeding experiments $\mathrm{s}^{2}$ - would be expected to give rise to an accumulation of stabilized molecules, and hence to enhanced expression of antigenically recognizable class I molecules. The high peptide concentration required for this effect to be seen is clearly not necessitated by a low affinity of empty MHC molecules for peptide Schumacher et al. ${ }^{7}$ show that binding is rapid and, once bound, peptide does not dissociate - but probably because the lifetime of an empty class I molecule at the cell surface is so short. At lower temperatures they can be induced to survive for longer, in which case less peptide is required $^{6,7}$.

Thus there are now two ways to increase class I expression at the RMA-S cell surface: lowering the temperature of culture, and incubation with specific peptides. Ljunggren et $a l^{\circ}{ }^{\circ}$ find that the two treatments are synergistic, indicating that peptide is more effective at surface stabilization, but that lower temperature increases the rate at which empty class I molecules successfully navigate the exocytic pathway.

From these new results it seems that enhanced class I expression in peptide-fed RMA-S cells can be explained by cellsurface stabilization of a flux of empty $\mathrm{H}-2$ molecules, involving a small proportion of total $\mathrm{H}-2$ heavy chains synthesized by the cells. How then does one explain the following observations of Townsend $e t$ al. ${ }^{2}$ : first that in extracts from cells both peptide-fed and biosynthetically radiolabelled a significant proportion of heavy chains were induced to assemble with $\beta 2 \mathrm{~m}$, and second, that these heavy chains are sensitive to endoglycosidase- $\mathrm{H}$ and therefore should derive from an intracellular, pre-Golgi compartment? Under the conditions used in those experiments, a long incubation with peptide followed by a shorter radiolabelling period, it is likely that most empty $\mathrm{H}-2$ molecules that actually bound peptides at the surface of intact cells, would not have been radioactive and would thus have been 'invisible' to immunoprecipitation, electrophoresis and autoradiography. A clue that the observed association of newly synthesized polypeptides in peptide-fed cells might not result from an in vivo process was the fact that almost all $\beta 2 \mathrm{~m}$-associated heavy chains remained in immature endoglycosidase $\mathrm{H}$-sensitive forms. This suggested that they were not moving from the Golgi complex to the plasma membrane as shown for class-I molecules in vivo ${ }^{13}$.

In extending and re-evaluating these observations, Townsend et al. ${ }^{8}$ now show the observed assembly can be accounted for by reactions occurring after disruption of the cells with detergent. They find that class-I assembly can in fact be induced by addition of peptide to extracts made from unfed RMA-S cells and similar results were seen on addition of extra $\beta 2 \mathrm{~m}$, providing independent evidence for the existence of empty molecules. A key experiment was to mix detergent lysates from two populations of RMA-S cells one peptide fed, the other radiolabelled

\title{
A head in the sands of time
}

WILD ostriches in naturalistic poses are among the most common motifs of the rock engravings of the Sahara. The numerous rock-art sites in the valley of the Enneri Blaka, Niger, are no exception: ostriches are depicted standing alone, or in groups, and sometimes as the quarry of hunters. A prehis. toric engraving of what appears to be a domesticated ostrich has now been discovered $^{1}$, confounding the view that these birds were domesticated only in historical times.

In the past, one very schematic figure of an ostrich with a man on its back and holding its head had been claimed to represent domestic use of the species ${ }^{2}$ : other birds appear to bear packsaddles just like those in pictures of cattle from the same period. But such interpretations have not generally been taken seriously for the ostrich ${ }^{3}$.

The new discovery is a small, deeply engraved figure, attributed to the 'bovidian' style, and hence to the Neolithic period between about 7,000 and 5,000 years ago (see figure, after $E$. Tillet: scale bar, $10 \mathrm{~cm}$ ). Located in rocks on the left bank of the River Blaka, it shows an ostrich in left profile. The wings and feathers are not shown, and the legs are folded beneath the reclining body. The lines above have been interpreted ${ }^{\prime}$ as some kind of load, tied up with a series of straps, and perhaps fixed to the ostrich at the neck and rump.

In Africa, much use was made throughout prehistory of ostrich feathers for decoration, and of its eggshells for vessels and beads, but it was believed that vessels and beads, but it was believed that
there was no ancient attempt at domestication. It is known that the Egyptians occasionally caught young ostriches and broke them to the harness: in the Graeco-Roman period, eight ostriches drew the ceremonial chariot of King Ptolemy Philadelphus, and his queen sometimes rode on one 4 . But true domestication has often been attributed to French experiments in North Africa in the late nineteenth century.

The new discovery, together with the other figures considered doubtful or enigmatic until now, may prompt a reevaluation of the role of this useful bird in early times.

Paul Bahn

Paul Bahn is a freelance writer on archaeology based at 428 Anlaby Road, Hull HU3 GQP, UK.

1. Tillet, T. Bull. Soc. preh/st. Fr. 87, 139-140 (1990).

2. Lhote, H. Les Gravures de loued Mammanet (Nouvelles Editions Afrlcalnes, Dakar, 1979).

3. Monod, T. L'Adrar Ahnet (Institut d'Ethnologle de Monod, T. L'Adrar Ahnet
l'Université de Paris, 1932).

4. Hyams, E. Animals in the Service of Man (Dent, London, 1972). 